\title{
Characterization of producers and quinoa supply chains in the Peruvian regions of Puno and Junin
}

\author{
Waldemar Mercado*; Karina Ubillus
}

Facultad de Economía y Planificación - Universidad Nacional Agraria La Molina, UNALM, Apartado postal 12-056, La Molina, Lima, Peru.

Received December 21, 2016. Accepted May 26, 2017.

\begin{abstract}
The present study aims to categorize quinoa producers and examine and compare quinoa supply chains in the Peruvian regions of Puno and Junin. This research was conducted in the provinces of San Roman and El Collao in Puno and Jauja and Huancayo in Junin using surveys of producers selected according to stratified sampling, along with interviews and workshops with traders and agents in the supply chain. Cluster analysis was used to examine the producers' attributes, the supply chain, and the profit margins of conventional and organic producers. In both regions, most producers were small and medium sized (100\% in Puno and $91.6 \%$ in Junin). The supply chains in Puno and Junin comprised 24 and 31 channels, respectively. It was found that numerous collectors, formal and informal processors, and exporters mainly linked with organized producers participated in these supply chains and this made trade efficient and coordinated. In contrast, trade among individual producers in the domestic markets through agents in the supply chain was highly disjointed, tending toward high centralization and without added value. It is concluded that quinoa supply is complex, centralized, traditional, and somewhat inefficient since asymmetrical relations were found between agents favoring commercial intermediaries.
\end{abstract}

Keywords: quinoa; commercialization; production costs; agricultural markets; supply chains.

\section{Introduction}

Agrarian commerce comprises all activities undertaken to achieve the delivery of agricultural products from the point of production to the final consumer through internal and external markets (Martínez, 2005; Mendoza, 1991).

The supply chain is a network that allows the transfer of a product, representing the relationship among agents and the movement of the product from its origin to its destination (Coscia, 1978). According to Alarcón and Ordinola (2002), the typology of the network determines whether the chain is direct or indirect and whether the commerce is centralized (when one agent primarily dominates the network) or decentralized.
Production costs are the economic value of resources incurred for obtaining goods over a period of production; in other words, these are input costs associated with manual labor, land costs, and depreciation, among other variables (Álvarez and Sánchez, 1998). To determine the profitability of the producer, the production costs and the producer's selling price are required. In general, the larger and more complex the supply channel, the greater will be the marketing costs and the lesser will be the producer's selling price. The market tends to offer only one price at the point of sale.

Research on quinoa marketing in Peru has focused on the following aspects: (1) exports, along with the identification of 
potential markets and the trends therein and determination of requirements to access wealthier countries (FAO and ALADI, 2014; MINAGRI, 2013); (2) the characteristics of quinoa demand in Lima, Peru, and its consumption across various socioeconomic strata (IMA Opinion and Mercado, 2013; Chacchi, 2009); (3) regional marketing and identification of Puno's production chain (Bermejo, 2009; IICA, 2015; MINAGRI, 2013; MINCETUR, 2006) and the commercialization of quinoa in Junin and Arequipa (IICA, 2015; Mercado and Gamboa, 2014); and (4) food security evidencing that producers prefer to sell quinoa and consume foods that are less expensive and less nutritious (IICA, 2015; Laqui, 2013).

In 2015, Peru exported 42 thousand tonnes of quinoa, whereas Bolivia, another great producer of the grain, exported 25.1 thousand tonnes. This made the country former the world's leading quinoa exporter (CCEX, 2016). In 2016, according to statistics from Agrodataperu (2016), the volume exported by Peru reached 43.8 thousand tonnes, with quinoa ranking $14 / 150$ in terms of exports of nontraditional products. However, the free-onboard (FOB) value decreased $27 \%$ from U.S.\$ 143.55 million in 2015 to U.S.\$ 103.16 million in 2016. Despite this decrease, it must be recognized that in Peru, the extraordinarily dynamic promotion of quinoa over the past decade has resulted in the expansion of its cultivation from the Andes to the Coast.
Quinoa production in Peru has grown significantly, from 22 thousand tonnes in 2001 to 105 thousand tonnes in 2015, with an annual growth rate of $15 \%$ (MINAGRI, 2016).

In 2016, the Puno region exhibited the highest quinoa production, although its production has decreased relative to the national production (Table 1). In 2001, Puno was responsible for $81 \%$ of the national production, but by 2016 , this share had fallen to $45.2 \%$. Next, the Southern high mountain region in Peru (comprising four departments, including the departments of Arequipa and Ayacucho, which have larger productions) accounted for $40.6 \%$ of the total in 2016. In third place was the Peruvian Coast (with seven departments), which represented $5.1 \%$ of the total, followed by Junin in fourth place with $4.9 \%$. The Central and North high mountain region came last, accounting for $4.1 \%$ of the total. In all cases, the mean annual growth rate over 2001-2016 was positive. In 2016, production in all regions decreased as a result of falling selling prices of quinoa producers. This study's objectives are to categorize quinoa producers and determine and compare quinoa supply chains in the principal producing regions of Puno and Junin. The Puno region "the Altiplano" is between 3812 and 5500 m.a.s.l. and has a cold but temperate climate because of nearby Lake Titicaca. The lake receives rainfall from December to March and determines the cultivating season (GRP, 2008).

Table 1

Quinoa production by region (2001-2016)

\begin{tabular}{|c|c|c|c|c|c|c|c|c|c|c|}
\hline \multirow[b]{2}{*}{ Region } & \multicolumn{8}{|c|}{ Quinoa production (thousand tonnes) } & \multirow[b]{2}{*}{$\begin{array}{l}\text { Growth } \\
\text { rate }\end{array}$} & \multirow[b]{2}{*}{$\begin{array}{c}\text { Percentage } \\
\text { in } 2016\end{array}$} \\
\hline & $\begin{array}{l}\text { Mean } \\
2001- \\
2005\end{array}$ & $\begin{array}{l}\text { Mean } \\
2006- \\
2010 \\
\end{array}$ & 2011 & 2012 & 2013 & 2014 & 2015 & 2016 & & \\
\hline Puno & 22.9 & 27.3 & 32.8 & 30.2 & 29.3 & 36.2 & 38.2 & 35.2 & $5.6 \%$ & $45.2 \%$ \\
\hline Junin & 1.4 & 1.3 & 1.4 & 1.9 & 3.9 & 10.5 & 8.5 & 3.8 & $5.6 \%$ & $4.9 \%$ \\
\hline $\begin{array}{l}\text { Southern high } \\
\text { mountain (1) }\end{array}$ & 2.8 & 4.7 & 5.5 & 10.2 & 15.1 & 49.5 & 47.1 & 31.6 & $15.4 \%$ & $40.6 \%$ \\
\hline $\begin{array}{l}\text { Central and Nortt } \\
\text { high mountain (2) }\end{array}$ & 0.9 & 0.9 & 1 & 1.2 & 1.6 & 5.7 & 4.8 & 3.2 & $8.7 \%$ & $4.1 \%$ \\
\hline Coast (3) & 0.4 & 0.4 & 0.5 & 0.8 & 2.2 & 12.8 & 6.9 & 4.0 & $15.1 \%$ & $5.1 \%$ \\
\hline Total & 28.4 & 34.5 & 41.2 & 44.2 & 52.1 & 114.7 & 105.6 & 77.8 & $8.7 \%$ & $100.0 \%$ \\
\hline
\end{tabular}

(1) Arequipa, Apurimac, Ayacucho, Cusco; Puno is excluded in this list. (2) Huancavelica, Ancash, Cajamarca, Amazonas, Pasco, Huanuco; Junín is excluded in this list. (3) Lambayeque, La Libertad, Ica, Lima, Moquegua, Piura, Tacna. Source: Ministry of Agriculture and Irrigation (MINAGRI) (2016). 
Table 2

Principal quinoa metrics for Junin and Puno regions (2008-2016)

\begin{tabular}{|c|c|c|c|c|c|c|c|c|c|}
\hline & $\begin{array}{c}2008- \\
2009\end{array}$ & $\begin{array}{c}2009- \\
2010\end{array}$ & $\begin{array}{c}2010- \\
2011\end{array}$ & $\begin{array}{c}2011- \\
2012\end{array}$ & $\begin{array}{c}2012- \\
2013\end{array}$ & $\begin{array}{l}2013- \\
2014 \\
\end{array}$ & $\begin{array}{c}2014- \\
2015\end{array}$ & $\begin{array}{l}2015- \\
2016\end{array}$ & $\begin{array}{l}\text { Growth } \\
\text { rate }\end{array}$ \\
\hline \multicolumn{10}{|c|}{ Puno region } \\
\hline Sown area (ha) & 26110 & 27047 & 28360 & 30265 & 31258 & 32929 & 34640 & 36430 & $4.87 \%$ \\
\hline Production (t) & 31174 & 31946 & 32743 & 30179 & 29331 & 36158 & 38221 & 35166 & $1.74 \%$ \\
\hline Yield (kg/ha) & 1194 & 1213 & 1198 & 1100 & 981 & 1121 & 1119 & 985 & $-2.71 \%$ \\
\hline $\begin{array}{l}\text { Farm price } \\
\text { (soles/kg) }\end{array}$ & 3.46 & 3.44 & 3.73 & 4.01 & 5.78 & 5.08 & 5.59 & 4.09 & $2.42 \%$ \\
\hline \multicolumn{10}{|c|}{ Junin region } \\
\hline Sown area (ha) & 1028 & 1153 & 1211 & 1432 & 5404 & 4191 & 4272 & 2012 & $10.10 \%$ \\
\hline Production (t) & 1454 & 1586 & 1448 & 1882 & 10551 & 8040 & 8518 & 3800 & $14.71 \%$ \\
\hline Yield (kg/ha) & 1414 & 1375 & 1216 & 1314 & 1998 & 2002 & 1994 & 1893 & $4.30 \%$ \\
\hline $\begin{array}{l}\text { Farm price } \\
\text { (soles/kg) }\end{array}$ & 3.20 & 3.53 & 3.91 & 4.10 & 5.79 & 3.28 & 3.27 & 3.79 & $2.45 \%$ \\
\hline
\end{tabular}

Source: Authors' elaboration using data from DRAP (2017) and DRAJ (2017).

The agrarian sector represented $17 \%$ of the gross regional product in 2011. The area of land cultivated for quinoa expanded $4.9 \%$ annually on average from 2008 to 2016; planting occurs between August and November and harvests from April to May. During the same period, quinoa production grew by $1.7 \%$ on average and the yield decreased by $2.7 \%$ annually (Table 2 ). According to National Institute of Agricultural Innovation (INIA) interviewees, this reduction is attributed to the delayed rains that result in postponed sowing, particularly since the yield in Puno is influenced by climate and applied technology.

In Puno, in 2016, the land cultivated for quinoa was concentrated in Azangaro (8220 ha), San Roman (5,130 ha), Puno (4920 ha), El Collao (4728 ha), Huancane (3690 ha), and Chucuito (3500 ha). Further, quinoa is most important in terms of cultivated areas in San Roman (27\%) and El Collao (22\%) (DRAP, 2016). From 2008 to 2016, a positive correlation is established between prior farm prices and current sown area in El Collao $(r=0.76)$ and San Roman $(r=0.45)$ according to data from DRAP (2016).

Based on the National Agrarian Census (INEI, 2012), the Puno region had 56353 farmers dedicated to quinoa production, equivalent to $82 \%$ of the quinoa farmers in Peru. These farmers, on average, cultivated less than 3.0 ha, used traditional technology, and farmed a great variety of products to militate against climatic and geophysical risks (in the mountainous Puno region, the weather and altitude prohibit drastic changes in production). According to the same census, in Junin, there were 1601 farmers producing quinoa, which represents $2.3 \%$ of the national total; of these farmers, $75.8 \%$ cultivated the grain on less than 3.0 ha.

Junin is located in central Peru and has an altitude that varies between 400 masl and 5,730 masl. In terms of prevailing climate and biomes, the region varies from mountainous glaciers to tropical forests (GRJ, 2008). The agrarian sector represented $6.71 \%$ of the gross national agrarian product in 2016. The surface area cultivated with quinoa increased at a rate of $10.1 \%$ on average between 2008 and 2016; planting occurs from October to December, with harvests from May to July. Production has grown by an average of $14.7 \%$ annually and the yield has increased at a rate of $4.3 \%$ annually (Table 2). However, in 2016 , the sown area fell by $53 \%$ compared with the previous year, and the total quinoa production decreased by $55 \%$. At the provincial level, quinoa cultivation is most concentrated in Huancayo (848 ha) and Jauja (669 ha). It is also cultivated in Concepcion (329 ha), Chupaca (147 ha), and Tarma (8 ha). Quinoa cultivation only represents $1.62 \%$ of the total cultivated land area in the region and only $0.14 \%$ of total regional production (DRAJ, 2016). According to data reported by DRAJ (2016) from 2008 to 2016, there is a positive correlation between prior farm 
prices and current sown area in the provinces of Huancayo $(r=0.76)$ and Jauja $(r=0.89)$.

The present research used the following categories to differentiate between quinoa in terms of production regimes: (i) traditional quinoa, which is characterized by the predominant use of organic fertilizers and rain-fed irrigation in the production process; (ii) conventional quinoa, which principally uses chemical inputs as fertilizers and pesticides and is associated to under irrigation crop by the contour-furrow method; and (iii) certified organic quinoa, for which the production process has been adapted to standards required by certifiers.

\section{Material and methods}

This study considered the most representtative provinces and districts of quinoacultivating areas in Puno and Junin, where information was gathered by surveying quinoa producers in 2014 (Figure 1). Following Arvizu et al. (2014), a mixedmethods (qualitative and quantitative) approach was followed.

In Puno, there were 11388 quinoa farmers in the provinces/districts examined in the present study (INEI, 2014), 240 of which were sampled. Among the districts of San Roman, 22 of these producers were based in Cabana, 25 in Caracoto, and 6 in Cabanillas. Among the districts of $\mathrm{El}$ Collao, 136 producers were based in Ilave and 51 in Pilcuyo. The sample size was determined through an equation of finite sample populations. Additionally, 30 further surveys were administered to intermediate agents (collectors, wholesalers, millers, processors, retailers, nongovernmental organizations, and local government officials) to identify the relation between agents and market destinations. To estimate the production costs, 30 additional surveys were administered to traditional producers and organically certified producers: 21 in El Collao and 9 in San Roman.

In Junin, there were 1690 quinoa farmers in the districts covered by this study (INEI, 2014), of which 190 farmers were included in the sample by using a two-stage stratified sampling conglomerate, stratified with probability proportional to the size of the conglomerate that is used when the population is divided in groups that represent the total of the variable in the study.

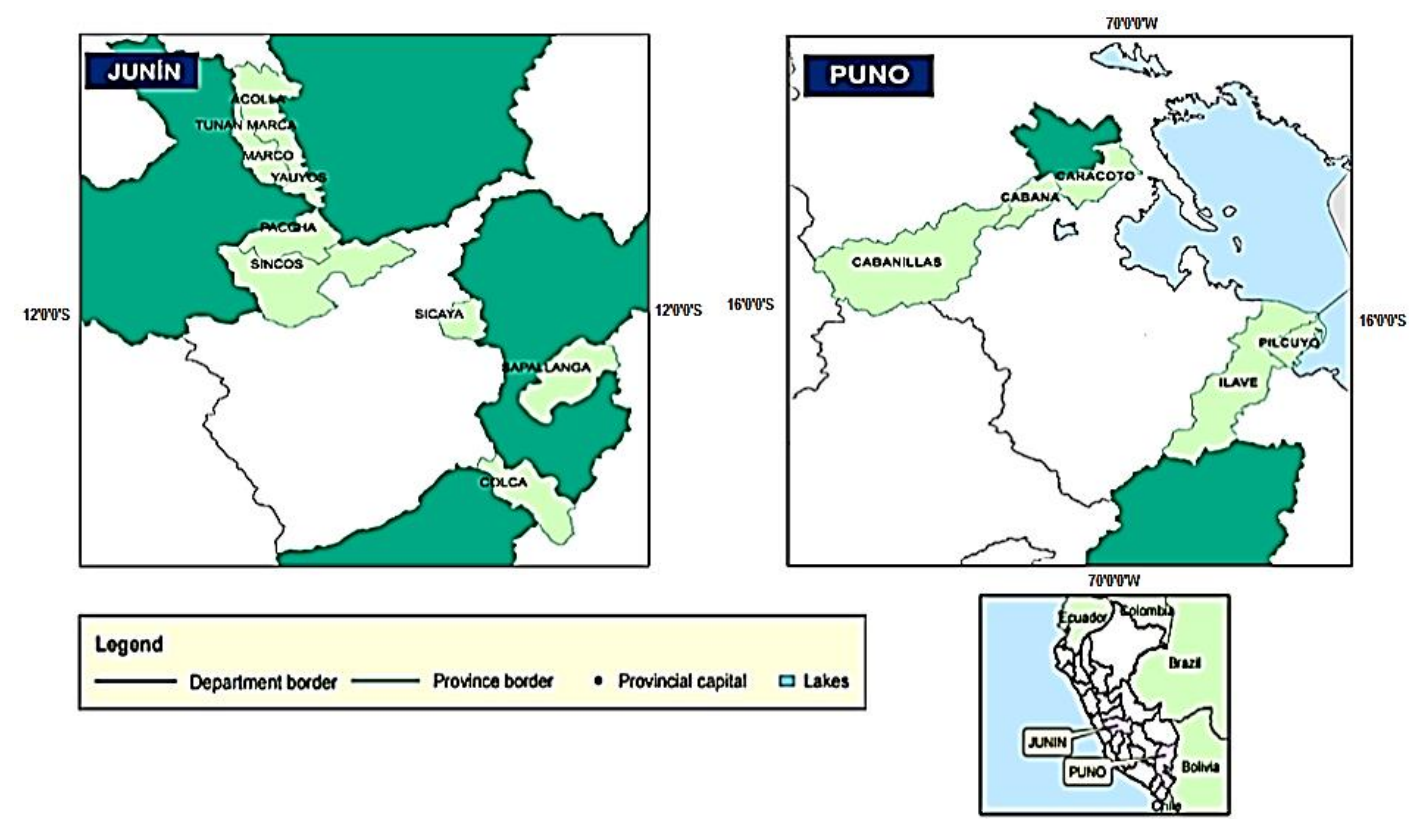

Figure 1. Maps of the main quinoa producer districts in Junin and Puno where the interviews were conducted. 
Specifically, 47, 20, and 18 producers were surveyed in Sicaya, Colca, and Sapallanga, respectively (districts of Huancayo), and $34,16,12,8,15$, and 20 producers were surveyed in Acolla, Marco, Yauyos, Tunan Marca, Paccha, and Sincos, respectively (districts of Jauja). Additionally, 36 additional surveys were administered to various agents in the supply channel. To estimate the production costs, information was gathered from various local associations of producers and governmental agricultural agencies in Jauja and Huancayo. This information was contras-ted with six surveys taken from producers in Jauja and Huancayo, who represented the average producers of those zones.

The surveys administered to producers covered the following topics: (i) information related to quinoa production (size of cultivated land, access to productive inputs, technical services, suppliers, and quantity of production); (ii) distribution of the harvest between sales, storage for later sale, self-consumption, self-supply, and destination of product according to the buyer and the market; and (iii) details of the producer.

The surveys administered to marketers covered the following topics: (i) type of agent and purchase volume; (ii) quinoa source, purchase price, varieties, and color; and (iii) destination, purchase price, volume, commercialized quinoa products, and certifications that are used (see Annex). The surveys concerning production costs covered the following topics: (i) details of producers; (ii) property details, harvested area, production and certifications; (iii) and production costs, renting and land preparation, sowing, agricultural work, harvesting, inputs used, applied fertilizers, cost of packaging and transportation, credit, and unexpected costs.

\section{Results and discussion}

\subsection{Characterization of quinoa producers}

Characterization, as per Tobar (2010), involves determining the particular attributes of someone or something and distinguishing them or it from comparable entities. Typing is the act of representing the subject or object using types, classes, or categories based on its principal characteristics (Bolaños, 1999).

The characteristics of quinoa producers in El Collao and San Roman are now discussed. First, $20 \%$ of them belonged to an association, whereas $98 \%$ of those surveyed were owners of their own land. The average area of land cultivated was 2.97 ha, distributed in 2 to 4 parcels. In El Collao, $35 \%$ of the cultivated land was dedicated to quinoa production, $30 \%$ to oats, and $21 \%$ to potatoes. In San Roman, $39 \%$ of the land was dedicated to the cultivation of oats, $27 \%$ to quinoa, and $14 \%$ to barley. On average, the producers had cultivated quinoa in Puno for more than 18 years.

Cluster analysis aims to classify individuals into groups so that there is more homogeneity within groups with respect to the observed variables. This methodology has hitherto been used specifically in the context of quinoa by Ton and Bijman (2006), coffee by Hernández-Martínez (2008), and agricultural products more generally by Santos (2014). This analysis allowed the quinoa producers to be classified in groups of small- and medium-sized producers. Of these, $65 \%$ were small-sized producers who, on average, dedicated 0.51 ha to the cultivation of quinoa for 2.49 ha that they cultivated in total, producing $314 \mathrm{~kg}$ of quinoa with an average yield of $603 \mathrm{~kg} / \mathrm{ha}$. Further, 35\% were medium-sized producers with 1.33 ha of cultivated quinoa, producing $1089.3 \mathrm{~kg}$ of quinoa with an average yield of $803.4 \mathrm{~kg} / \mathrm{ha}$ (Table 3). Similar data were obtained by Flores and Chura (2015) for the district of CabanaPuno.

Of the total interviewed in Puno, 91\% produced traditional quinoa and $9 \%$ certified organic quinoa; in San Roman, 35\% produced certified organic quinoa and $65 \%$ produced traditional quinoa. The varieties of quinoa cultivated in Puno were Kancolla (34.4\%), Pasankalla (24.8\%), Blanca de Juli (21.3\%), and Salcedo INIA (18.4\%). 
Because of the market preference for white quinoa, only $1 \%$ of the cultivated quinoa was not white.

In Junin, $21.6 \%$ of the quinoa producers belonged to an association $(2.4 \%$ were small-sized producers, $85.4 \%$ mediumsized producers, and $12.2 \%$ large-sized producers). The members of associations were able to sell approximately $15 \%$ of their quinoa through formal agreements for which they received the highest price. They also had greater accessibility to financing, machinery, and training (Ton and Bijman, 2006). Of all the producers $59 \%$ were owners of the land they cultivated, and $72 \%$ of them obtained their land through inheritance. On average, each producer owned 4.8 ha under cultivation, and all the Junin producers were characterized by having a lower level of information with respect to the market, such as buyers, markets, characteristics the buyers are looking for, and how prices are set.

Of the Junin producers, $24.2 \%$ were smallsized producers who dedicated, on average, 0.67 ha to quinoa cultivation (of the 1.9 ha under cultivation) to produce $780 \mathrm{~kg}$ of quinoa with a yield of $1279 \mathrm{~kg} / \mathrm{ha}$ (close to the average yield of small familiar producers in Northwest Argentina) (Golsberg, 2013). They retained 25.9\% of the production for their own consumption. The majority, i.e., $67.4 \%$, were mediumsized producers who dedicated, on average, 1.42 ha to the quinoa cultivation (of the 3.9 ha under cultivation), produced an average yield of $2125 \mathrm{~kg} / \mathrm{ha}$, and sold $93.9 \%$ of their total production. Finally, $8.4 \%$ were large-sized producers who dedicated, on average, 9.23 ha to quinoa cultivation (of the 20.4 ha under culti- vation), produced a yield of $2617 \mathrm{~kg} / \mathrm{ha}$, and sold $98.6 \%$ of their total production (Table 4). For comparison, according to Jacobsen (2003), the yield is, on average, $1000 \mathrm{~kg} / \mathrm{ha}$ in the United States; 2280 $\mathrm{kg} / \mathrm{ha}$ in Italy; and $3960 \mathrm{~kg} / \mathrm{ha}$ in Greece.

Across all producers, 95.8\% produced conventional quinoa and traditional quinoa and only $4.2 \%$ produced certified organic quinoa, the latter being produced in the districts of Sincos (Jauja) and Sapallanga (Huancayo). The varieties cultivated are white $(84.7 \%)$, the two types being (1) Hualhuas and Blanca de Junin and (2) colored quinoa, black, and red (15.3\%).

As seen from Tables 3 and 4, there are significant differences between the producers of quinoa in Puno and Junin. The producers in Puno tended to be smaller and produced smaller yields. In Junin, they primarily produced conventional quinoa, whereas in Puno, they tended to produce traditional quinoa and certified organic quinoa.

\subsection{Chain of production and market destination of quinoa}

Identified herein is the farmers' relationships in the chain of quinoa production "backward" and "forward" (Figure 2), demonstrating that access of the producers to the input providers and technical services is better in Junin than in Puno. Therefore, $86 \%$ of the farmers in Junin used machinery such as tractors compared with $82 \%$ in Puno (97\% in Puno and $82 \%$ in Junin rented the tractor). Further, 29\% had undergone training and $29 \%$ had received technical assistance in Junin compared with $16 \%$ and $6 \%$, respectively, in Puno.

Table 3

Characterization of surveyed quinoa producers in Puno's provinces (2014)

\begin{tabular}{l|cc|ccc|c}
\hline \multirow{2}{*}{ Variables } & \multicolumn{2}{|c|}{ San Roman } & \multicolumn{2}{c|}{ El Collao } & \multicolumn{2}{c}{ Total } \\
\cline { 2 - 6 } & Small & Medium & Small & Medium & Small & Medium \\
\hline Number of producers & 51 & 6 & 103 & 80 & 156 & 84 \\
\% of total & $90 \%$ & $10 \%$ & $56 \%$ & $44 \%$ & $65 \%$ & $35 \%$ \\
Cultivated area (ha) & 2.05 & 3.98 & 2.71 & 3.84 & 2.49 & 3.85 \\
Cultivated area of quinoa (ha) & 0.46 & 1.75 & 0.53 & 1.30 & 0.51 & 1.33 \\
Production of quinoa (kg) & 229.4 & $1,266.7$ & 358.4 & $1,076.7$ & 314.1 & $1,089.3$ \\
Yield of quinoa (kg/ha) & 554.3 & 788.8 & 732.8 & 817.9 & 603.0 & 803.4 \\
\hline
\end{tabular}




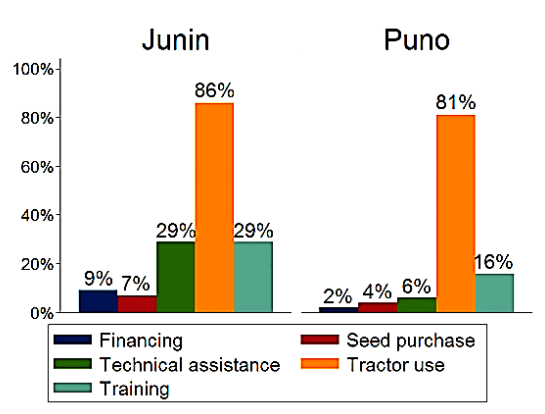

(a)

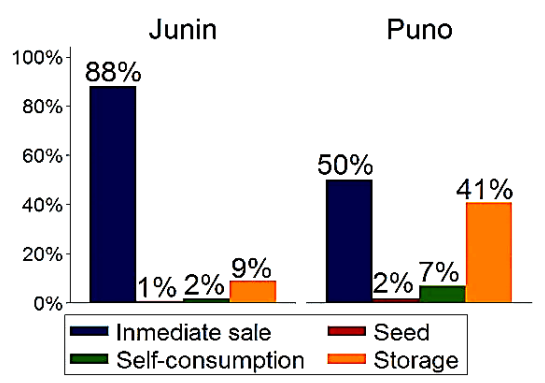

(b)

Figure 2. Articulations of surveyed quinoa producers in the supply chain in Puno and Junin (2014): (a) Access to productive inputs; (b) Destination of quinoa production.

Private financing was opted for by only $2 \%$ in Puno and $9 \%$ in Junin. Regarding seeds, $96 \%$ of the producers in Puno obtained them from previous production processes and only $4 \%$ bought them from the INIA; producers also exchanged seeds among themselves. In Junin, 93\% obtained seeds from previous production processes and $7 \%$ bought them from the INIA. In Puno, producers tended to use local inputs and had limited access to providers of finance and technical assistance; this situation is in contrast to the case of producers in Bolivia (Montoya et al., 2005), Colombia (Dueñas, 2014), and Argentina (Golsberg, 2013). Production "forward" represents the possible destinations of the produced quinoa. Although some quinoa was stored for later sale in both regions, this was more evident in Puno than in Junin (41\% versus $9 \%$ ). Hence, in Junin, $88 \%$ of the quinoa produced was sold upon harvesting and 9\% was stored for future sale; this means that $97 \%$ of the production was commerciallized. In Puno, a relatively higher portion of the quinoa produced was consumed by the producer and set aside for the seeds (9\%) than in Junin (3\%). In Puno, the stored grain was sold when the producers required capital. The harvest was sold to Type I collectors (called "K'ato"), who operated in local fairs $(3.8 \%)$ and to Type II collectors, who operated in urban areas (93.2\%).

In Puno, the producers delivered the product to the point of sale $2.9 \%$ of the time. In Junin the harvest was sold to Type I collectors (22\%) wholesalers (21\%) retailers $(14.5 \%)$ and businesses $(16.4 \%)$. The remaining $14 \%$ was sold directly to consumers at fairs $(3.3 \%)$ the Jauja market $(0.6 \%)$ Huancayo $(7.2 \%)$ and mills $(2.9 \%)$. The market destinations of quinoa from Puno were as follows: (1) the regional market in Puno accounted for $10.7 \%$ (including the quantities consumed by the producer and set aside for seeds) of the total; (2) markets in other departments (Arequipa Cusco and Tacna) represented $4.4 \%$ of the total; (3) the national market in Lima received $24.4 \%$ for urban consumption or processing for later sale to consumers; and (4) international market accounted for $19.5 \%$ (Table 5).

\section{Table 4}

Characterization of surveyed quinoa producers in Junin's provinces through cluster analysis in two phases

\begin{tabular}{l|ccc|cccc|ccc}
\hline \multirow{2}{*}{ Variables } & \multicolumn{3}{|c|}{ Huancayo } & \multicolumn{3}{c|}{ Jauja } & \multicolumn{3}{c}{ Total } \\
\cline { 2 - 12 } & Small & Medium & Large & Small & Medium & Large & Small & Medium & Large \\
\hline Number of producers & 12 & 63 & 10 & 34 & 65 & 6 & 46 & 128 & 16 \\
\% of total & 14.1 & 74.1 & 11.8 & 32.4 & 61.9 & 5.71 & 24.2 & 67.4 & 8.4 \\
\hline Cultivated área (ha) & 2.52 & 4.27 & 20.37 & 1.65 & 3.5 & 20.33 & 1.9 & 3.9 & 20.4 \\
Cultivated area of quinoa (ha) & 0.76 & 1.75 & 9.37 & 0.64 & 1.1 & 9.00 & 0.67 & 1.42 & 9.23 \\
\hline Production of quinoa (kg) & 739 & 3771 & 24095 & 795 & 2493 & 21367 & 780 & 3122 & 23072 \\
Yield of quinoa (kg/ha) & 1080 & 2180 & 2583 & 1349 & 2072 & 2674 & 1279 & 2125 & 2617 \\
\hline
\end{tabular}


The market destinations of quinoa from Junin were as follows: (1) the regional market in Junin accounted for $44.1 \%$ (including the quantities consumed by the producer and set aside for seeds) of the total; (2) markets in other departments (Jungle) represented $0.1 \%$; (3) the national market in Lima accounted for $42.4 \%$; and (4) international markets received $3.8 \%$. Under the assumption that the stored quinoa for later sale $(41 \%$ and $9 \%$ in Puno and Junin respectively) is sold to destinations similar to those sold to after harvesting in 2014 Puno's production would have first supplied the Lima market $(24.4 \%)$ followed by the international market $(19.5 \%)$ and regional markets including nearby departments (15.1\%). For Junin the main destination was the regional market $(54 \%)$ followed by the Lima market $(42 \%)$ and the international market (4\%). Thus, Puno's production exhibited better performance in dynamic markets positioning the traditional quinoa and the certified organic quinoa. Meanwhile Junin's production of conventional quinoa mainly served regional markets and given to its proximity to Lima its destination markets were mostly the popular ones.

\subsection{Intermediary agents in the quinoa supply chain}

Puno's quinoa supply chain is illustrated in Figure 3 representing all commercial agents therein.

a) Producers sold $22.02 \%$ of the total quinoa produced to Type I collectors in local fairs (well known as K'ato) and $22.17 \%$ to Type II collectors at regional fairs. The latter also bought from Type I collectors (1.09\%) and commercialized $23.25 \%$ of the total volume. There were also direct channels wherein the producer sold $0.01 \%$ to retail markets in Ilave and Juliaca (channel 1) and $5.80 \%$ was commercialized by organized producers such as Cooperativa Agro Industrial Cabana Ltda (COOPAIN) which sold traditional quinoa (channel 21, $0.26 \%$ of the total) and certified organic quinoa $(5.55 \%)$. COOPAIN exported quinoa to the U.S.A., Germany, Canada, the Netherlands and France (channels 22, 23 and 24) via the Cabana 3901 Organic Whole Foods brand.

b) Collectors gathered produce for wholesale. Type I collectors collected quinoa in local fairs and sold to millers and processors in Juliaca (13.2\% of the total) and to Type II collectors in Juliaca (1.1\%). Type II collectors were provided by producers $(22.17 \%)$ and Type I collectors who in turn sold to Lima processors (Channel 9, 10.5\%) wholesalers $(6.43 \%)$ exporters $(4.9 \%)$ Juliaca processors $(0.9 \%)$ and Arequipa and Cusco markets $(0.52 \%)$. According to the calculations from collectors interviewed in Juliaca in 201430 collectors existed in Juliaca and around 80 in the province of San Roman this number is higher than reported by Sierra Exportadora (2013).

c) Among the processors Juliaca millers channeled $1.9 \%$ of the output (channel 3) consisting of washed white quinoa $(90 \%)$ and colored (10\%). They also bought recently harvested quinoa at prices between 8 and 10 soles $/ \mathrm{kg}$ and sold the product washed between 13 and 15 soles $/ \mathrm{kg}$. Of the total production $24.63 \%$ was channeled through processors that transformed the product into quinoa pearled washed in flakes and in flour among other processed products. There were 13 companies identified at that level that commercialized organic and traditional quinoa. Exporter companies based in Puno (there were 11 in 2013) exported washed quinoa organic colored quinoa tricolor quinoa and other processed products; traditional white quinoa quinoa flakes precooked quinoa gourmet pearled quinoa and colored quinoa in the fair-trade market (Flo Fair Trade) (Adex Data Trade, 2015).

d) Processing and exporting companies in Lima were supplied from several parts of Peru. In 2013 there were 86 such companies that exported 13301 tonnes of quinoa in total; 9\% of Puno's production was delivered to these companies. 
Table 5

Destination markets of quinoa produced in Puno and Junin based on survey of quinoa producers

\begin{tabular}{|c|c|c|c|c|c|c|}
\hline \multirow{2}{*}{$\begin{array}{l}\text { Characteristic } \\
\text { Markets }\end{array}$} & \multicolumn{3}{|l|}{ Puno } & \multicolumn{3}{|c|}{ Junin } \\
\hline & Type of agent & $\%$ & Total & Type of agent & $\%$ & Total \\
\hline Seeds & Producer & $2.0 \%$ & $2.0 \%$ & Producer & $1.2 \%$ & $1.2 \%$ \\
\hline Self-consumption & Producer & $7.0 \%$ & $7.0 \%$ & Producer & $1.9 \%$ & $1.9 \%$ \\
\hline Storage & Later sale & $41.0 \%$ & $41.0 \%$ & Later sale & $9.0 \%$ & $9.0 \%$ \\
\hline \multirow{4}{*}{ Intra-regional } & & & \multirow{4}{*}{$1.7 \%$} & Local fairs & $8.6 \%$ & \multirow{4}{*}{$41.7 \%$} \\
\hline & Ilave and & $0.0 \%$ & & Huancayo and & $23.1 \%$ & \\
\hline & $\begin{array}{l}\text { Juliaca retail } \\
\text { Juliaca wholesale }\end{array}$ & $0.3 \%$ & & $\begin{array}{l}\text { Jauja markets } \\
\text { Social programs }\end{array}$ & $9.8 \%$ & \\
\hline & Puno wholesale & $1.4 \%$ & & Huancayo Municipality & $0.2 \%$ & \\
\hline Inter-regional & $\begin{array}{l}\text { Arequipa and Cusco processors } \\
\text { Other wholesalers }\end{array}$ & $\begin{array}{l}1.1 \% \\
3.3 \%\end{array}$ & $4.4 \%$ & $\begin{array}{l}\text { Social programs } \\
\text { Markets in Jungle }\end{array}$ & $0.1 \%$ & $0.1 \%$ \\
\hline \multirow{4}{*}{ National (Lima) } & Collector in Lima & $0.2 \%$ & \multirow{4}{*}{$24.4 \%$} & & \multirow{2}{*}{$42.3 \%$} & \multirow{4}{*}{$42.4 \%$} \\
\hline & Wholesaler & $8.3 \%$ & & Markets in Lima & & \\
\hline & Processors in Lima & $11.4 \%$ & & Supermarkets & $0.1 \%$ & \\
\hline & Exporters & $4.5 \%$ & & & & \\
\hline \multirow[t]{2}{*}{ International } & $\begin{array}{l}\text { U.S.A. Germany Canada } \\
\text { Netherlands and France }\end{array}$ & $10.6 \%$ & \multirow[t]{2}{*}{$19.5 \%$} & \multirow[t]{2}{*}{ Exportation } & \multirow[t]{2}{*}{$3.8 \%$} & \multirow[t]{2}{*}{$3.8 \%$} \\
\hline & Exporters & $9.0 \%$ & & & & \\
\hline Total & & $100 \%$ & $100 \%$ & & $100 \%$ & $100 \%$ \\
\hline
\end{tabular}

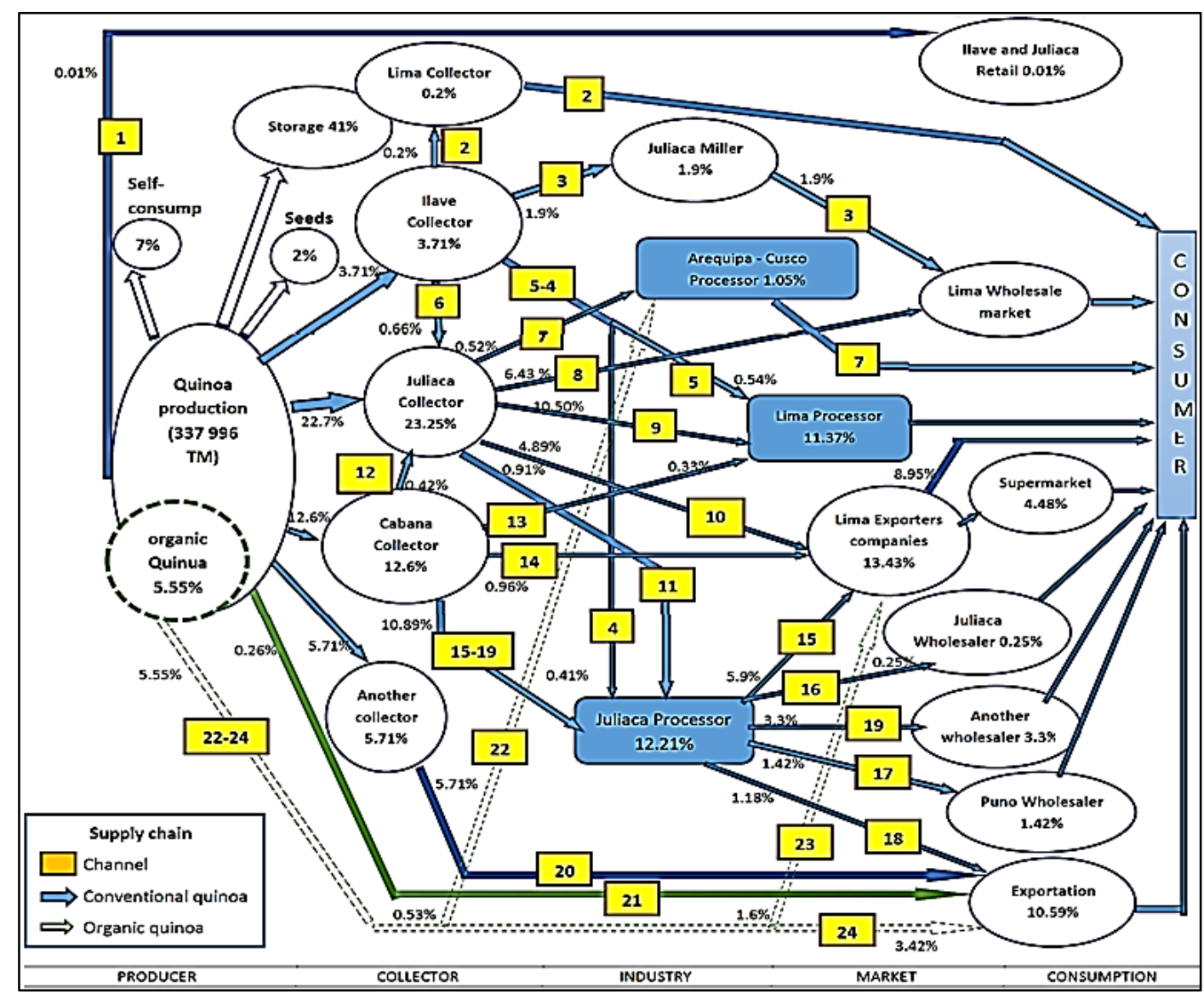

Figure 3. Quinoa supply chain in the region of Puno based on surveyed producers and suppliers.

e) Wholesalers allocated $8.33 \%$ of Puno's quinoa production to markets in Santa Anita and La Parada in Lima where they sold the product washed pearled in flakes or in flour to retailers and consumers. Moreover, they also supplied to wholesale 
markets in Juliaca and Puno (1.42\%) and to extra-regional wholesalers in Arequipa Tacna and Cusco (3.3\%).

f) Supermarkets in Puno and Juliaca (Plaza Vea and Via Market) and Arequipa and Cusco (Plaza Vea) along with the supermarket network in Lima (which received $4.48 \%$ of Puno's production) sold pocketed pearled quinoa and quinoa as flakes grains energy bars breakfast items candies and other variants. District fairs and the retail trade in municipal markets in El Collao Puno and Juliaca where quinoa was marketed jointly with other grains beans and cereals accounted for $0.01 \%$ of the total sold. The local governments of llave Cabana and Juliaca used to buy quinoa for social programs; this was terminated in 2014 because of rising prices.

Therefore, the quinoa supply chain in Puno comprised 21 indirect channels involving individual and organized producers collectors millers processors and export markets (Fig. 3). The quinoa supply chain was mainly centralized and governed by collectors (Type I and II) who comercialized $39.56 \%$ of the total production $(50 \%$ of which was commercialized at harvest). The direct organic marketing channels (channels 1, 21 and 24) of producer organizations were also identified. Channel 1 was short and with close spatial proximity thereby guaranteeing availability to the Juliaca market of Ilave and local food security therein. Channels 21 and 24 were short channels but far in spatial terms because they consisted of an intermediary for the international market through COOPAIN which sells with certifications and incorporates added value through product brands.

Junin's quinoa supply chain is presented in Figure 4.

a) Producers sold at local fairs $22.02 \%$ of the total quinoa through indirect channels to Type I collectors (small) next $20.97 \%$ was sold to Type II collectors (medium) $14.53 \%$ to Type III collectors (wholesalers) and $2.88 \%$ to millers. Through direct channels $16.43 \%$ was sold to Type I companies that transformed and sold directly to Lima's market which were exporters $3.31 \%$ in fairs (channel 1) $7.17 \%$ to the Huancayo wholesale market (channel 3) and $0.59 \%$ to the Jauja market. Finally, $12.1 \%$ was allocated for selfconsumption storage and seeds.

b) Collectors gathered produce to sell it directly without intermediation. Type I collectors gathered quinoa at fairs and sold directly to final consumers $(1.55 \%)$ millers and processors in Jauja and Huancayo $(10.76 \%)$ and wholesalers $(9.72 \%)$ (Type II collectors). Type II collectors were supplied by producers $(20.97 \%)$ and Type I collectors with the main destination being processors in Lima through Type III collectors (channel 26 12.16\%) and direct means $6.62 \%$ (channel 19). The retail Type III collectors sold to Type II companies that supplied quinoa to social programs $(17.17 \%)$ Type I companies $(0.95 \%)$ and markets in Lima $(12.16 \%)$. According to interviews to collectors and processors calculations 67 such collectors consisting of at least 30 millers and 30 processor companies which agrees with data obtained by SNV (2013).

c) Millers of Huancayo transformed up to $22.47 \%$ of the produce $(20.53 \%$ washed and $1.94 \%$ pearled). They were supplied by Type I collectors $(10.76 \%)$ producers $(2.88 \%)$ and Type III collectors (6.81\%). Of the total production $20.08 \%$ was supplied to formal processors (Type I companies) that transformed the quinoa into pearled washed extruded and processed quinoa and as flakes and flour. A total of 20 companies were identified at that level that commercialized conventional quinoa in small proportions. Four of these companies were exporters based in Junin that exported 3.78\% in grain (Adex Data Trade, 2015). Type II companies only packaged the quinoa and branded it for comercialization prior to serving social programs such as Qali Warma. These companies sold $16.72 \%$ of the processed quinoa to markets in Lima.

d) Wholesalers allocated $6.62 \%$ of the quinoa production to markets in Santa Anita and La Parada in Lima (channel 19) 
where commercialized the product for retailers and consumers as washed and pearled quinoa or as flakes and flour. A further $6.12 \%$ was allocated to the Huancayo market (channel 22) and $0.66 \%$ to Type II companies. Retailers supplied mainly to Type II companies (17.17\%) markets in Lima (12.16\%) and Type I companies $(0.95 \%)$.

e) Supermarkets sold quinoa pocketed and pearled and as flakes grain energy bars breakfast items candies and other variants in Huancayo (Plaza Vea) and the network of supermarkets in Lima which received $0.082 \%$ of the production. Social programs in Huancayo received $9.81 \%$ extraregional social programs accounted for $0.051 \%$ and local government received $0.22 \%$.
Junin's quinoa supply chain comprised 28 indirect channels involving individual and organized producers collectors millers processors exporters and traders and target markets (Figure 4). It was a centralized supply chain and governed by Type II collectors (who commercialized $37.31 \%$ of the quinoa production) and companies (both Type I and Type II which comercialized $51.9 \%$ of the production). Three direct channels existed from producer to consumer (channel 1 at local fairs channel 2 to Jauja markets and channel 3 to Huancayo markets). These channels were short and close in spatial terms guaranteeing availability to local markets and providing a basis for the maintenance of food security.

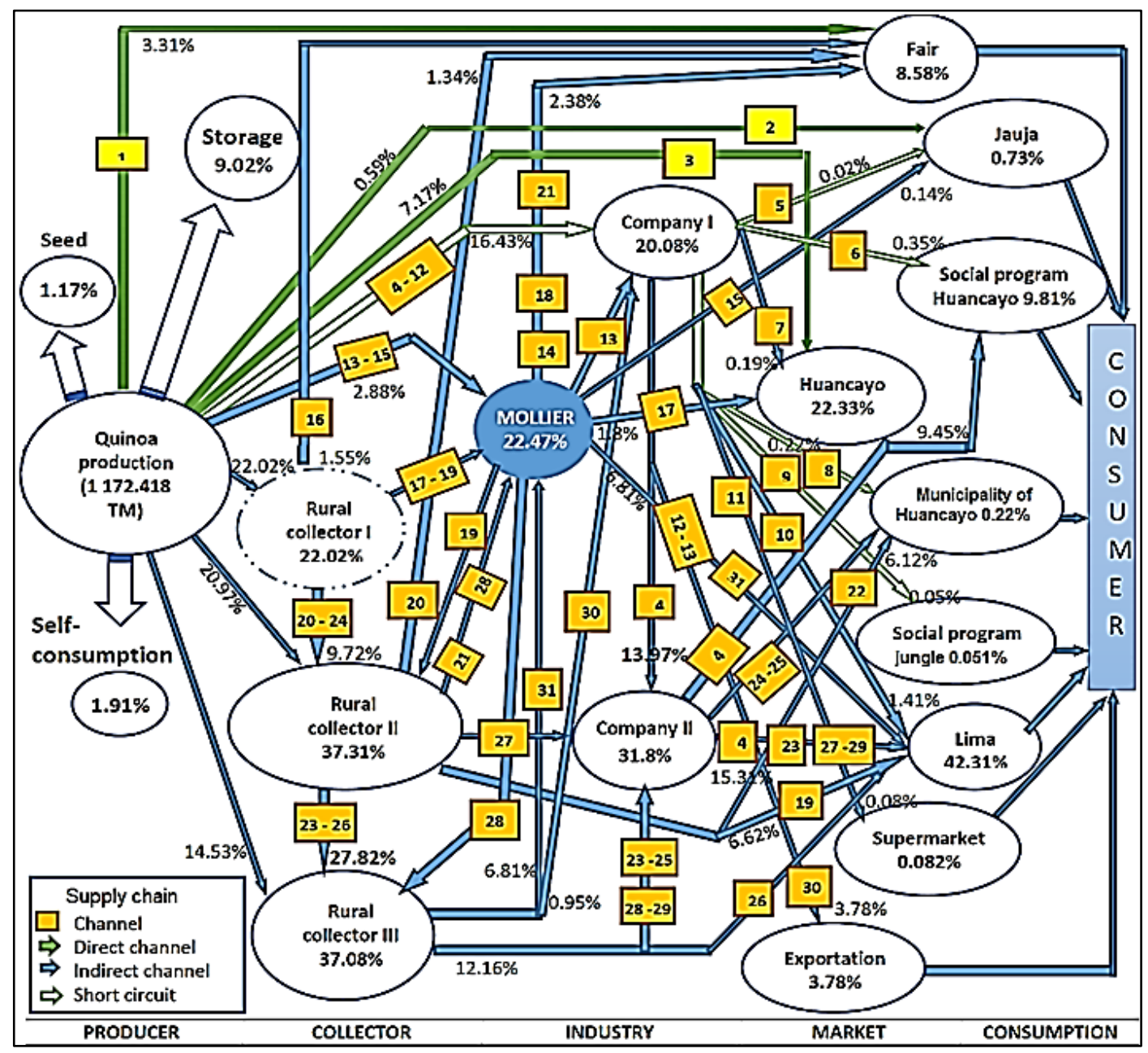

Figure 4. Quinoa supply chain in the region of Junin based on surveyed producers and suppliers. 
The principal bottlenecks in the comercialization of quinoa were fourfold: (i) the lack of unity and strength among producer associations and their links with other agents in the supply/production channel which reduced their ability to decrease costs and increase efficiency (Ton and Bijman, 2006; Arvizu et al., 2014); (ii) the lack of producer power vis-à-vis negotiation results in increased profits for intermediaries and decreased profits for the producers; (iii) problems with quality not meeting minimum standards of presentation traceability proof of origin (organic conventional or traditional) thereby impeding penetration into markets and reducing competitiveness (Fairlie, 2015; OIT, 2015) while simultaneously undermining local food security; and (iv) the absence of support and incentives for modernization and guaranteed access to input products and technical services that could be implemented through public policy.

\subsection{Costs of quinoa production in Puno and Junin}

Quinoa production costs in Puno and Junin are delineated in Table 6 . The calculations were standardized to a per-hectare basis to facilitate comparison. Direct costs include land rent (opportunity cost at local value); preparation of land; labor and machinery used (sowing labor and harvesting); and inputs such as seeds fertilizers packaging and transport. Indirect costs consider administrative and unexpected expenses as $5 \%$ of the total direct costs and social laws as $46 \%$ of labor costs (VLIR-UOS, 2013). Thus, total costs per hectare of quinoa include direct and indirect costs.

In Puno, traditional small-sized producers and small-sized organic farmers incurred costs $11.1 \%$ and $8.3 \%$ respectively higher than their medium-sized counterparts. Yields are reported by surveyed farmers and costs per $\mathrm{kg}$ are derived from them. Income depends on the crop performance and the price received because it fluctuates throughout the year. Prices reported in DRAP (2016) were used for regional representation. Profitability indicates how much producers earn for every sol spent; it was high in 2014 for the traditional crop because of higher performance and lower costs. Meanwhile the profitability for certified organic producers was higher because performance was reflected in price similar to the findings reported by Fairlie (2015).

For Junin total costs incurred per hectare include direct and indirect costs. (For data collection costs based on activities and activity-based costing methods were used.) Small-sized producers incurred costs $2.07 \%$ lower than medium-sized producers (because many small-sized producers incurred lower equipment and labor costs). However they incurred costs $12.47 \%$ higher (highest costs incurred) than largesized producers because the latter can obtain higher yields per $\mathrm{kg}$ of quinoa.

There is an important difference between the price received by small-medium- and large-sized producers because of their relative bargaining power and because a group of medium- and large-sized producers can sell their produce to companies (e.g. Álicorp Ecoandino) that set the price according to the quality of quinoa produced. Since prices reported in DRAJ (2016) were used producers' size made a difference. Profitability in 2014 was higher for medium- and large-sized producers because of higher performance compared with that for smaller-sized producers.

Therefore, the profitability of quinoa in 2014 was high because of prices received by producers. It was the highest in Junin where producers responded more quickly to market signals to increase production that year. In 2015 production was lower in Junin because of lower producer prices. In Puno production is still growing because there is little scope for alternating between commercial crops in the Peruvian plateau region. Moreover, quinoa is positioned in the local culture and has lower total production costs; this grain provides local food security and finally reaches domestic and foreign markets which are relatively more dynamic and demanding of the final product. 


\section{Table 6}

Total costs per sown hectare and economic metrics associated with quinoa rates in Puno and Junin based on surveyed quinoa producers in Puno and Junin

\begin{tabular}{l|cccc|ccc}
\hline \multirow{3}{*}{ Characteristic } & \multicolumn{4}{|c|}{ Puno } & \multicolumn{3}{c}{ Junin } \\
\cline { 2 - 9 } & \multicolumn{3}{|c}{ Traditional } & \multicolumn{2}{c|}{ Organic } & \multicolumn{3}{c}{ Conventional } \\
\cline { 2 - 8 } & Small & Medium & Small & Medium & Small & Medium & Large \\
\hline Total costs (soles) & 2410 & 2190 & 2420 & 2234 & 5423 & 9301 & 9861 \\
Yield (kg/ha) & 732 & 792 & 701 & 735 & 1279 & 2125 & 2617 \\
Cost (soles/kg) & 3.29 & 2.77 & 3.45 & 3.04 & 4.0 & 4.0 & 4.0 \\
Prices (soles/kg) & 6.5 & 6.5 & 7.2 & 7.2 & 6.0 & 7.0 & 7.0 \\
Average income (soles) & 4758 & 5148 & 5047.2 & 5292 & 7572 & 15714 & 19106 \\
\hline Profitability & $97 \%$ & $135 \%$ & $109 \%$ & $137 \%$ & $140 \%$ & $169 \%$ & $194 \%$ \\
\hline
\end{tabular}

For producers to obtain a greater portion of the price paid by consumers they must establish more direct relationships with purchasers of quinoa in the supply channel. Additionally, the government should purchase quinoa for food programs directly from the producer and promote local programs to finance quinoa producers and add value to quinoa as proposed by Furche et al. (2013). It is also necessary to create a system that would identify the traceability of the collective brand of Puno and Junin because these are the only two Peruvian regions that continue to produce native varieties of quinoa.

\section{Conclusions}

(i) In Puno, the principal destination for quinoa was outside of the region although the local market was also significant. In this region producers tended to use local inputs and had limited access to providers of finance and technical assistance. In Junin the farmers enjoyed greater access to these providers and were able to respond more rapidly to market/price changes. However, they still lack the ability to penetrate larger markets and negotiate with local commercial agents. Further there is no possibility of adding value to the raw quinoa resource and the local producer associations are weakly organized.

(ii) In general, when producers interact with the supply chain at a smaller level (individual) rather than through an organized association the supply channels are centralized through collectors. Consequently, the supply chain leading to the final consumer is highly disorganized and inefficient characterized by asymmetries. Further the limited ability of the small-sized producers to negotiate impedes cooperation between producers and other members of the supply chain. In contrast when producers are well organized they sell through supply chains that are more efficient and have direct links to processors as demonstrated in Puno.

(iii) In the production of traditional and organic quinoa in Puno the costs for smallsized producers were greater than those incurred by medium-sized producers. This demonstrates the possibility of reducing costs through economies of scale and stronger producer associations. The profitability of organic production was slightly higher than that of traditional production owing principally to the reduced price received upon sale. In Junin the medium- and large-sized producers obtained greater profit owing to their greater yields. In both cases cultivation was profitable but could be improved if crop yields were improved through financing technology training and research.

Taking this study's findings into considerations the following recommendations for future research: (a) broaden and deepen the typology of producers by for example recognizing that because different categories exist differentiated public policies are necessary; (b) further explore supply chain nuances and complexities by identifying interactions between agents so that public policies can promote productive improvement and added value through trade; (c) identify new alternatives as vertical integration between producers and marketing agents; and (d) examine the short-circuit promotion at the regional and national levels and its relation with food security public purchased fair market and the boom of gastronomy. 


\section{Acknowledgments}

To the staff at the Agrarian Agency of El Collao and San Roman (DRA-Puno) and Huancayo and Jauja (DRA-Junin). I also thank the research assistants (M. Apaza, C. Gamboa and G. Díaz) and translators (M. Altshuler and J. Huerta) involved in this research for their support and inputs. I duly acknowledge financial support from Mercados Campesinos (AVSF-CEPES) and the University Cooperation VLIRUOS - UNALM.

\section{References}

Alarcón, J.; Ordinola, M. 2002. Mercadeo de Productos Agropecuarios: Teoría y aplicaciones al Caso Peruano. First edition. Lima Peru.

Adex Data Trade Aduanas 2015. Estadísticas sobre las exportaciones de quinua. Database.

AGRODATAPERU. 2016. Estadísticas Exportaciones Agropecuarias. Lima-Perú.

Álvarez, A.; Sánchez, B. 1998. Costos y métodos de costeo: Aplicación y análisis para el sector agropecuario. First edition. Bogota Colombia.

Arvizu, E.; Jiménez, L.; Jimenes, A. 2014. Análisis de producción y comercialización de hortalizas: caso del mercado de Huixcolotla Puebla. Revista Mexicana de Ciencias Agrícolas 5: 687-694.

Bermejo, R. 2009. Producción y comercialización de quinua y cañihua ecológica en la Provincia de MelgarPuno. First edition. Puno Peru.

Bolaños, O. 1999. Caracterización y tipificación de organizaciones de productores y productoras. Paper presented at XI Congreso Nacional Agronómico. July 19-23 Costa Rica.

CCEX. 2016. Cámara de Comercio de Lima. Estadísticas Importaciones/Exportaciones. Lima-Perú.

Chacchi, K. 2009. Demanda de la quinua a nivel industrial. UNALM. Lima Peru.

Coscia, A. 1978. Comercialización de productos agropecuarios. First edition. Buenos Aires Argentina.

DRAJ - Dirección Regional de Agricultura de Junin. 2016. Estadisticas agropecuarias del departamento de Junin de los años 2008-2016. Junin, Peru.

DRAP - Dirección Regional de Agricultura de Puno. 2016. Estadisticas agropecuarias del departamento de Puno de los años 2008-2016. Puno, Peru.

Dueñas, D. 2014. Vigilancia competitiva de la quinua: potencialidad para el departamento de Boyacá. Ed. Elsevier. Revista Suma de Negocios 5 (12): 85-95.

Fairlie, A. 2015. Cadena exportadora y políticas de gestión ambiental de la quinua en el Peru. Red LATN Serie Crecimiento Verde e Inclusivo. Working Paper 179.66.

FAO; ALADI. 2014. Tendencias y Perspectivas del comercio internacional de la Quinua. Santiago Chile.

Furche, C.; Salcedo, S; Krivonos, E. 2013. International quinoa trade. In State of the art report on quinoa around the world in 2013. Edited by D. Bazile D. Bertero \& C. Nieto. Chapter 4.1 316-329 (Rome: FAO \& CIRAD) 605.

GRJ - Gobierno Regional de Junin. 2008. Plan Desarrollo Regional Concertado Junin al 2015. Junin, Peru.

GRP - Gobierno Regional de Puno. 2008. Plan Desarrollo Regional Concertado Puno al 2021. Puno, Peru.

Golsberg, C. 2013. Organización de la Agricultura Familiar en el Noroeste de Argentina para la producción de quinua. INTA. Revista Ciencia y Tecnología de los Cultivos Industriales 3(5): 85-92.

Hernández-Martínez, G. 2008. Clasificación Agroecológica. In Agroecosistemas cafetaleros de Veracruz: biodiversidad manejo y conservación. Edited by Manson R.H. Hernández-Ortiz V. Gallina S. y Mehltreter K. Chapter 2, 14-34 (Mexico: Instituto de Ecología A.C. e Instituto Nacional de Ecología) 348.

IICA - Instituto Interamericano de Cooperación para la Agricultura. 2015. El mercado y la producción de quinua en el Peru. First edition. Lima, Peru.

IMA Opinión; Mercado. 2013. Sondeo de consumo en quinua: Lima Metropolitana y Callao. Lima. Documento en ppt sin publicar. Database.

INEI - Instituto Nacional de Estadística e Informática. 2014. IV Censo Nacional Agropecuario 2012. CENAGRO Database.

Jacobsen, S. 2003. The Worldwide Potential for Quinoa (Chenopodium quinoa Willd.). Food Reviews International 19: 167-177.

Laqui, C. 2013. Cadena productiva de la quinua en la Región Puno. Documento sin publicar.

Martínez, F. 2005. Comercialización Agropecuaria: Un enfoque económico de las estrategias comerciales. First edition. Santiago, Chile.

Mendoza, G. 1991. Compendio de Mercadeo de Productos Agropecuarios. Second Edition.

Mercado, W.; Gamboa, C. 2014. Comercialización de la quinua en las provincias de Chupaca y Jauja en la Región Junin. In Debate Agrario Análisis y Alternativas 46. Lima, Peru. 93-117.

MINCETUR - Ministerio de Comercio Exterior y Turismo. 2006. Plan operativo de la quinua en la Región Puno. Mesa de trabajo de la quinua en Puno. Puno, Peru.

MINAGRI - Ministerio de Agricultura y Riego. 2016. Estadísticas Agrarias. Lima, Peru.

MINAGRI - Ministerio de Agricultura y Riego. 2013. Principales Aspectos de la cadena agroproductiva de la quinua en el Peru. Lima, Peru.

Montoya, L. Martínez L.; Peralta J. 2005. Análisis de variables estratégicas para la conformación de una cadena productiva de quinua en Colombia. Revista INNOVAR 15(25): 113-119.

Santos, V. 2014. Tipología de productores agropecuarios para la orientación de políticas públicas: Aproximación a partir de un estudio de caso en la región Texcoco, Estado de Mexico. Revista Sociedades rurales producción y medio ambiente 14(28): 47-69.

Sierra Exportadora. 2013. Directorio 2013 cadena productiva de la quinua en el Perú. Lima, Peru.

SNV - Servicio Holandés de Cooperación al Desarrollo. 2013. Análisis de la cadena de valor de la quinua en los distritos de Sapallanga y Sincos - Región Junin.

OIT - Oficina Internacional del Trabajo. 2015. Análisis de la cadena de valor en el sector de la quinua en Peru: aprovechando las ganancias de un mercado creciente a favor de los pobres. First edition. Ginebra Switzerland.

Tobar, J. 2010. Criterios de tipificación y caracterización de la Agricultura Familiar en El Salvador. Nota Técnica No 5 FAO-AECID GCP/ELS/008/SPA.

Ton, G.; Bijman J. 2006. The role of producer organizations in the process of developing an integrated supply chain; experiences from Quinoa chain development in Bolivia. 7th International Conference on Management in AgriFood Chains and Networks Ede The Netherlands 31 May - 2 June.

VLIR- UOS 2013. Manual de cultivo de la quinua. Second Edition. (Lima: Universidad Nacional Agraria La Molina y CONCYTEC) 48. 


\section{Anex}

Survey administered to quinoa marketers
Name:
Districts of provenance:

$\mathrm{N}^{\circ}$

A. Type of agent
( ) Producer
( ) Transformer (new products)
( ) Collector
( ) Retailer
( ) Processor (post-harvest)
( ) Wholesaler

B. What is the volume of quinoa you bought in the last campaign and/or year?

( ) Certified

( ) Conventional

( ) Both

C. What is the origin the volume and purchase price of quinoa?

\begin{tabular}{|c|c|c|c|c|c|}
\hline Agent & Region & Province & District & Volume $(\mathrm{kg})$ & Price (soles $/ \mathrm{kg})$ \\
\hline & & & & & \\
\hline & & & & & \\
\hline Total & & & & & \\
\hline
\end{tabular}

D. What is the destination volume and sale price of quinoa?

\begin{tabular}{|c|c|c|c|c|c|}
\hline Agent* & Region & Province & District & Volume $(\mathrm{kg})$ & Price (soles $/ \mathrm{kg})$ \\
\hline & & & & & \\
\hline & & & & & \\
\hline Total & & & & & \\
\hline
\end{tabular}

* Agroindustry processor export market (local/regional) and fairs

E. Which products are marketed (in \%)?

\begin{tabular}{|l|l|l|l|l|l|}
\hline \multirow{2}{*}{\multicolumn{1}{|c|}{ Products }} & \multirow{2}{*}{$\%$} & \multicolumn{4}{c|}{ Certification } \\
\cline { 3 - 6 } & & Organic & Sanitation & Quality & Others \\
\hline At harvest & & & & & \\
\hline Flour & & & & & \\
\hline Flakes & & & & & \\
\hline Pearled & & & & & \\
\hline Washes & & & & & \\
\hline Others & & & & & \\
\hline
\end{tabular}

F. What kind of activities do you undertake before selling quinoa?

Why?

\begin{tabular}{l|l|l|l}
\multicolumn{1}{c|}{ YES } \\
Washing \\
\cline { 2 - 4 } $\begin{array}{l}\text { Selection } \\
\text { Packing } \\
\text { Storage } \\
\text { Transportation } \\
\text { Others }\end{array}$ & & & \\
\cline { 2 - 4 } & & & \\
\cline { 2 - 4 } & & & \\
\cline { 2 - 4 } & & & \\
\cline { 2 - 4 } & & & \\
\hline
\end{tabular}

G. Are there purchase contracts or agreements? With whom?

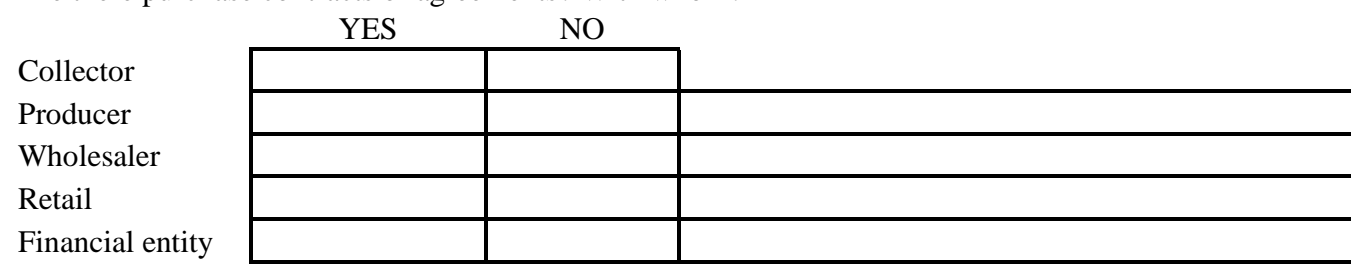

H. Do you provide some kind of proof of payment for buying and selling?

( ) Yes ( ) No 